\title{
The Influence of Peer Conformity and Perception of Authoritarian Parents' Parenting Patterns Against Religious Tolerance of Generation $\mathrm{Z}$ Adolescents in DKI Jakarta
}

\author{
Vika Nurul Mufidah', Nur Wahidin², Thobib Al-Asyhar ${ }^{3}$ \\ \{1 vikanurulm@gmail.com, ${ }^{2}$ nurwahidin@ui.ac.id, ${ }^{3}$ thobieb_smg@yahoo.com $\}$ \\ ${ }^{1,2,3}$ School of Strategic and Global Studies, Universitas Indonesia, Indonesia
}

\begin{abstract}
This study aims to determine whether there is an influence of conformity and perceptions about authoritarian parenting towards adolescent religious tolerance. There are 3 research questions formulated, namely: 1) Are there influences between conformity and perceptions of the authoritarian parenting of parents towards the religious tolerance of adolescent $z$ generation? 2) How big are these two predictors (conformity and perceptions of authoritarian parenting) that influence adolescent religious tolerance of generation $z$ ? 3) Which predictor most influences adolescent adolescent generation $\mathrm{z}$ tolerance: Conformity or perception of authoritarian parenting parents? This research is included in explanatory research. The study was conducted on high school students with a total subject of 300 people. The data collection tool is a questionnaire to measure all three variables. Data analysis was performed using multiple regression statistical techniques, with the help of SPSS version 16. From the results of data analysis, the regression model $\mathrm{Y}=15.20+0.729 \mathrm{X} 1-0.018 \mathrm{X} 2$, where $\mathrm{X} 1$ (conformity) became the best variable in influencing adolescent religious tolerance generation $\mathrm{z}$. This is seen from the coefficient of X1 of 0.727. In addition, it was also found that the percentage of $\mathrm{X} 1$ and $\mathrm{X} 2$ in influencing $\mathrm{Y}$ was $19.5 \%$ with a significance of 0.00 . This shows that there is a significant influence between conformity and perceptions of authoritarian parenting of parents towards adolescent generation $\mathrm{Z}$ tolerance.
\end{abstract}

Keywords: conformity, perception of authoritarian parenting parents, adolescent religious tolerance, generation $z$.

\section{BACKGROUND}

The number of teenagers in Indonesia has increased from year to year. The large number of adolescents can become a potential as well as a big problem for the country's development. One problem that is now often colouring the life of adolescence is religious tolerance. There are lots of data both from print and electronic media that illustrate the number of adolescents involved in being intolerant as in some of the following research surveys.

A study conducted by the International NGO Forum on Indonesian Development (INFID) regarding the perceptions and attitudes of the younger generation towards radicalism and violent 
extremism shows that young people are still classified as intolerant in responding to religious issues. $88.2 \%$ of them do not agree with violent extremism. But on the question of 'can you offer a holiday to another religious friend', the answer comparison is almost 50:50. The survey assessed that there was still intolerance among young people. The survey was strengthened by The Wahid Institute (2015) which collected as many as 306 students, and the results showed that as many as $27 \%$ of adolescents did not agree to say other people's religious holidays such as saying merry Christmas, while as many as $28 \%$ were still hesitant. then, $15 \%$ of students who will retaliate against their house of worship, are hesitant $27 \%$. While those who do not want to visit sick religious friends are as much as $3 \%$, while $3 \%$ are hesitant.

Furthermore, the Center for Islamic and Community Studies (PPIM) Syarif Hidayatullah UIN Jakarta (in tirto.id, 2017) on student perceptions, Generasi Z students concluded that there was an influence of intolerance and radicalism among generation $\mathrm{Z}$ (adolescents born in 19962010) in Indonesia. In the survey collected a sample of 1,522 students, 337 students, and 264 teachers in 34 provinces. Using a digital questionnaire and implicit association test, and conducted in the period of September-October 2017. Related to adolescents, in the study showed 48.95 percent of student / student respondents felt that religious education influenced them not to associate with other religions. (Muthahari, 2017). According to Santrock (2002), several predictors of juvenile delinquency include negative identity, self-control, age, gender, expectations for education, peer influence, socioeconomic status, parental role, and environmental quality. From several predictors that can cause juvenile delinquency, in this study more focused on examining the influence of peers and the role of parents or more specifically conformity and perceptions of authoritarian parenting parents.

Peer factors are one factor in adolescent involvement in religious tolerance. Patterson (Bowman, et al., 2007) explained that peers are one factor in the emergence of delinquency. As it develops, teenagers slowly begin to distance themselves from their families and start spending a lot of time interacting with their peers. According to Gottman and Parker (in Dariyo, 2004), one of the functions of friends in adolescent social development is as a motivator to stimulate a positive direction. This means that in relationships, teenagers should support each other to do positive things so that they influence their behavior in a positive direction too.

But in reality today many teenagers are involved in unhealthy relationships. Many of these teenagers who actually use relationships with peers to do negative things include being involved in intolerance. In explaining this problem, Santrock (2002) explains that conformity is one of the factors that causes many teenagers to do negative things along with their peers. According to Camarena (1991) and Wall (1993, in Santrock, 2002), conformity to peer pressure in adolescence can be positive or negative.

In addition to the influence of peers, the role of parents is also important in the emergence of intolerant attitudes in adolescents. Several studies that examined parenting explained that the type of parenting applied by parents would be related to the development of their teenage children, including the involvement of adolescents in religious tolerance. One parenting style that is related to the involvement of adolescents in intolerance is authoritarian parenting (Hoeve, et al, 2007). According to Hoeve, parenting causes juvenile delinquency. several studies have shown that authoritarian parenting does not affect religious tolerance.

Every parent must want everything that is best for their children. They have high hopes for their children and often make parents apply discipline. 


\section{THEORY STUDY}

\subsection{Conformity}

Conformity means submitting to the groups even though there is no direct request to follow what is done by the group. Conformity will result in a change in individual attitudes and behaviors that are carried out in accordance with existing social norms (Baron \& Byrne, 2005).

According to Baron and Byrne (2005), the basics that make a person conform to his group are because of the normative social influences (social normative influence) and informative social influences.

\subsubsection{Normative social influence (social normative influence)}

Normative social influences are social influences based on the desire of individuals to be liked or accepted socially. This normative social influence will cause changes in a person's behavior because of the desire of the individual to be able to fulfill the group's expectations so that he or she is not rejected by the group. The fear of rejection from the group makes the individual behave in accordance with the norms adopted by the group.

\subsubsection{Social influence is informative (social informative infuence)}

Social informative influence is social influence based on the individual's desire to feel right. Individuals will depend on the group as a source of information. This tendency to adjust based on the influence of information depends on two aspects of the situation, namely how much we believe in the group and how confident we are in our own judgment.

The greater our trust in information and group opinion, the more likely we are to adjust ourselves to that group. Anything that enhances our trust in group truths is also likely to increase our level of conformity.

\subsection{Perception of Authoritarian Parents' Parenting Patterns}

Hardy and Hayes (in Mussen, 1994) define parenting as a way that parents use to treat, raise, and care for children to help the next growth process. Parenting is all the behavior of parents to children through a system of rules, rewards, and communication that is applied at home. Several factors that influence parenting (Gunarsa, 2010):

1. Parents 'past experiences related to parenting or their parents' attitudes. Usually parents will use their parents' upbringing if it feels useful.

2. The values adopted by parents. Every person has different values in caring for their children. There are parents who prioritize intellectuals in their lives, or there are also those who prioritize spiritually, and so on.

3. Parent's personality type

4. The marriage life of parents

5. Reasons parents have children

Baumrind (1991, in Santrock, 2007), distinguishes parenting into several types, one of which is authoritarian parenting. Authoritarian parenting is a style of parenting that is punishing and limiting, where parents where parents try to make adolescents follow directions given by parents 
and respect the work and efforts that have been made by their parents. Parents who apply this parenting style will tend to limit the movement of adolescents and provide strict boundaries to adolescents so that they lack the opportunity to dialogue verbally with their parents and also have less opportunity to express their opinions.

Based on the explanation above, the understanding of the perception of authoritarian parenting parents is the view of adolescents who see that their parents are too strict in regulating, and controlling them, and urging them to do the rules arranged by parents without good communication with the teenager.

\subsection{Religious Tolerance}

This study, researchers used the definition of religious tolerance from Thalib. According to Talib (2009) who defines religious tolerance as a willingness to allow religious differences without prejudice or discriminatory behavior. Prejudice and discriminatory attitudes can be manifested in rejection by using political power, power, public or individual pressure, and so on. Religious tolerance also does not mean that someone assumes that other religions are as true as the religion adopted, but recognizes the rights of others to worship with the aim of creating harmony in society.

\section{PROBLEM FORMULATION}

Based on the background of the research above, the formulation of the problem in this study includes:

1. Are there influences between conformity and perceptions of the authoritarian parenting style of parents towards the adolescent tolerance of $\mathrm{Z}$ generation?

2. How much of these two predictors (conformity and perceptions of authoritarian parenting) have an effect on Religious Tolerance?

3. Which predictors most influence adolescent religious tolerance Conformity or perceptions of authoritarian parenting parents?

\section{RESEARCH METHODS}

This research is a quantitative research that is research where the data used is data in the form of numbers (score, value, rank, or frequency). When viewed from its purpose, this research is included in explanatory research, where this study highlights the relationship between research variables and examines the hypotheses previously formulated.

The variables used in this study are conformity, perceptions of Parental Authoritarian Parenting Patterns, and Generation Z Youth Adolescent Tolerance. These variables will be further explained below.

\subsection{Variable $X$ In this study is conformity and perceptions of the authoritarian parenting parents.}

Conformity variables are measured using a questionnaire that has been tested by researchers. Test the validity of the measuring instrument using content validity. The researcher asks for help from a number of Professional Judgments to help perfect this measure. While the 
coefficient of reliability of alpha cronbach's measuring instrument is 0.857 . This questionnaire consists of 25 items with 4 answer choices.

The perception variables of parents' authoritarian parenting were measured using questionnaires as well. The measuring instrument used in this study is a measuring instrument that has been tested and used in research conducted by Henny Nur Rahmania (2005) with the reliability coefficient of alpha cronbachr 0.8511 and produces 26 good items.

\subsection{The $Y$ variable in this study is religious tolerance}

This variable of adolescent religious tolerance is measured by a questionnaire that was also made by the researcher himself. This measuring instrument has also been tested and produced a Cronbach alpha reliability coefficient of 0.916. This questionnaire consists of 29 items using four answer choices, eliminating alternative middle answers.

This study uses adolescents aged 12-15 years who attend junior high school in the DKI Jakarta area. Determination of the characteristics of this sample is done because at adolescence (15-18 years), it is adolescence where they are in the initial transition period of childhood and also in early adolescence this attachment of adolescents with peers is in a significant position compared previous development phase. In addition, the level of adolescent conformity to antisocial standards set by peers tends to be high in early adolescence (Berndt, 1979, in Santrock, 2007).

To determine the sample used in the study, researchers used probability sampling namely convenience sampling as the sampling technique. Convenience sampling is sampling based on the availability of elements and the ease of getting them. Samples are taken / selected because the sample is in the right place and time.

The data analysis technique to see the effect of conformity and perceptions about the authoritarian parenting style of generation Z's religious tolerance is to use multiple regression analysis. This technique is carried out to analyze the effect of two variables $\mathrm{X}$ on one variable Y.

Before analyzing the data from the research results, the assumption test is carried out first. Test assumptions used are normality test, autocorrelation test, multicollinearity test, and homoskedasticity test.

\section{RESEARCH RESULTS}

After the rough data has been collected, the assumption test is carried out. The first assumption test is the normality test by observing the Normal Probability Plot (P-P) of The Regression Standardiez Residual in the results of the analysis. From the graph it can be seen that the data is located in a straight line from the lower left to the right so that it can be said to meet the assumption of normality. The second assumption test is the autocorrelation test by observing the Durbin-Watson coefficient. The Durbin-Watson coefficient obtained from the results of this analysis is 1,635 so that it can be assumed that autocorrelation does not occur. The third assumption test is the multicollinearity test using VIF coefficient and tolerance. VIF values show the number 1.019 and tolerance shows the number 0.981 so it can be said that there is no correlation between independent variables (conformity and perceptions of authoritarian parenting), and multicollinearity does not occur. The final assumption test is the homoskedasticity test. To find out whether this test is fulfilled or not, the Plots graph is used between the predicted value of the dependent variable, and the residual value. From the graph 
it can be seen that the points spread above and below the number 0 on the $\mathrm{Y}$ axis and there is no clear pattern so that the homoskedasticity test can be fulfilled.

After the assumption test is carried out, then the data analysis is then performed with regression techniques. From the ANOVA table, the coefficients of $F=24.704$ with sig $=0.00$ $<0.05$. This shows that the regression model is significant, which means that conformity and perceptions of authoritarian parenting parents have a significant effect on generation $\mathrm{Z}$ religious tolerance. The magnitude of the influence of predictor variables is explained by the $\mathrm{R}$ square number of 0.193 which means that parent's conformity and authoritarian parenting affect religious tolerance is $19.3 \%$, while the rest $(100 \%-19.3 \%=80.7)$ is influenced by other causes.

To find out how much the percentage of each of these predictors affects religious tolerance, it is seen from the value of $t$. Based on the table of analysis results, conformity has a value of $t$ $=6.986$ with $\operatorname{sig}=0,000$. This shows that the variable X1, namely confomitas, has a significant effect on the religious tolerance of adolescent $\mathrm{z}$ generation because the significance value is smaller than 0.05. While the Parental Authoritarian Parenting Perception shows the value of $\mathrm{t}=$ -0.188 with $\operatorname{sig}=0.851$. This shows that the variable $\mathrm{X} 2$, namely the perception of the authoritarian parenting style of parents does not significantly influence the religious tolerance of $\mathrm{Z}$ generation because the significance value is greater than 0.05 .

From the $\mathrm{F}$ test as explained above where the significance value is smaller than 0.05 , the regression model can be used to predict generation $\mathrm{Z}$ religious tolerance. The regression equation is:

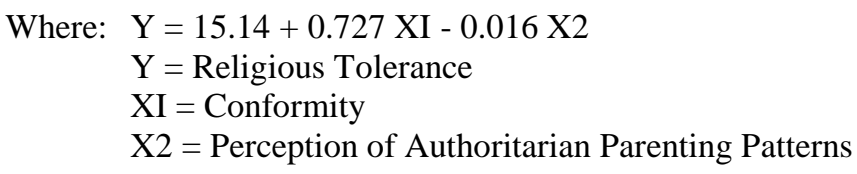

The constant of 15.14 states that if there is no conformity and the perception of authoritarian parenting parents, religious tolerance is 15.14 . The regression coefficient X1 of 0.727 states that any change in conformity of one unit will cause a change in religious tolerance of 0.727 . While the regression coefficient $\mathrm{X} 2$ of 0.016 states that each change in perception of authoritarian parenting by one unit will cause a change in $\mathrm{Y}$ of 0.016 . From this explanation it can be concluded that conformity is a greater predictor of adolescent religious tolerance compared to $\mathrm{X} 2$ perceptions of authoritarian parenting parents.

\section{DISCUSSION}

According to Konopka, early adolescence, aged 12-15 years, is the age at which adolescents begin to develop themselves into unique individuals and begin to no longer depend on their parents. Konopka also explained that the focus on this age is where conformity in early adolescents is still strong with peers.

Based on this Konopka opinion, it can explain why conformity has more influence in predicting religious tolerance. This is because in their early teens they developed conformity as an effort to be accepted by the group. As stated by Baron and Byrne (2005) that the basis of a person conforming to his group is because it is based on normative social influences where the individual has the desire to be liked or accepted by his group. According to Camarena (1991) and Wall (1993, in Santrock, 2002), conformity in adolescence can be positive or negative. According to Berndt (1979), Bernd \& Perry (1990), and Laventhal (1994; in Santrock, 2002: 46), more influential conformity to religious tolerance may also be due to the subject's own cultural factors. This study uses a subject with a cultural background in urban society (Jakarta), 
where the life of the Jakarta community is very thick with the existence of differences in social status. According to Sears, one factor in the appearance of conformity is due to social status factors. Status here includes status in any field where this status shows a symbol of appreciation for the individual because the status and position, he has is higher than the other individuals. Students who are the subjects of this study also live in the middle of a group with different social status which has a higher influence on influencing religious tolerance, probably due to the existence of values to better conform to their friends who have higher social status as a form of appreciation because of that higher position.

This is in line with the theory put forward by Sears as described above. Besides being a factor of social status, the collectivity factor can also be the reason why the subject is more conformable to his friends. In Jakarta society, the collective nature is inherent in daily life. As stated by Nyoman Naya Sujana (1994), namely that the people of Jakarta have a strong collective nature because they are born and developed in a social system that emphasizes togetherness, and customary systems. This collective nature can be seen from tolerance and mutual cooperation between people.

In the midst of the high value of the influence of conformity on adolescent religious tolerance, it turns out that this is not the case with the influence of perceptions about parental authoritarian parenting. In this study, the influence of parenting authoritarian parenting turned out to show a low influence on the tolerance of religious adolescents of generation $\mathrm{Z}$.

As you enter adolescence, individuals will tend to stay away from their parents and begin to turn their attention to their peers. Konopka also supports this where it is said that adolescents begin not to depend on their parents anymore. This allows adolescents to pay less attention to what is related to their parents, one of which is related to parenting. In accordance with the theory put forward by Walgito, where the perception process will occur if the individual focuses on a set of objects. Without attention, individuals cannot focus their attention on the stimulus so that perceptions cannot occur.

In applying parenting to children, parents are influenced by the culture that exists in their environment and are also colored by the problems that occur, guide and guide their children (Ali, 2010). The existence of cultural factors in determining parenting applied by parents to children causes a tendency for parenting to differ from one region to another.

The low influence of authoritarian parenting on juvenile delinquency may occur due to the characteristics possessed by the Jakarta community itself. The low influence of perceptions of authoritarian parenting in predicting adolescent religious tolerance may also be caused by the parenting style of the Jakarta community does not show parenting tend to be authoritarian. This is one of the weaknesses of this study, namely that the subject chosen by the researcher might come from a culture that does not tend to apply authoritarian parenting to children.

\section{CONCLUSION}

From the results of the research and discussion above, it can be concluded that:

a. There is a significant influence between conformity and perceptions of the authoritarian parenting of parents towards the religious tolerance of adolescent generation $\mathrm{Z}$.

b. Conformity is a greater predictor of influencing religious tolerance compared to the predictors of perceptions about parental authoritarian parenting.

\section{ACKNOWLEDGEMENT}


This research based on grant scheme of PITTA (Publikasi International Terindeks untuk Tugas Akhir) or also known as Indexed International Publications for Final Projects toward Universitas Indonesia students. Thank you to The Directorate of Research and Community Engagement of Universitas Indonesia (DRPM UI).

\section{REFERENCE}

[1]. Ali, Mohammad \& Asrori, Mohammad. (2010). Psikologi Remaja: Perkembangan Peserta Didik. Jakarta: PT Bumi Aksara.

[2]. American Psychological Association. (2002). A Reference for Professionals: Developing Adolescents. Washington DC: American Psychological Association.

[3]. Baumrind, D. (1966). Effects of Authoritative Parental Control on Child Behavior. Child Development, 37(4), 887-907.

[4]. Baumrind, D. (1967). Child care practices anteceding three patterns of preschool behavior. Genetic Psychology Monographs, 43-88.

[5]. Baron, R.A \& Byrne, D. (2005). Psikologi Sosial Jilid 2 edisi kesepuluh. Jakarta: Penerbit Erlangga.

[6]. Bowman, Marvella A., Prelow, Hazel M., \&Weaver, Scott R.(2007). Parenting Behaviors, Association with Deviant Peers, and Delinquency in African American Adolescents:A Mediated-Moderation Model. Journal of Youth Adolescene, 36, $517-$ 527.

[7]. Cohen, A. B., Wu, M. S., \& Miller, J. (2016). Religion and Culture: Individualism and Collectivism in the East and West. Journal of Cross-Cultural Psychology, 47(9), 12361249. Cozby, P. C. (2003). Method's in Behavioral Research (8th Edition). New York : Mc. Graw Hill.

[8]. Crandall, C. S., Ferguson, M. A., \& Bahns, A. J. (2013). When We See Prejudice: The Normative Window and Social Change. In C. Stangor, \& C. S. Crandall (Eds.), Stereotyping and Prejudice (pp. 53-70). New York: Psychology Press.

[9]. Darling, N., \& Steinberg, L. (1993). Parenting Style as Context: An Integerative Model. Psychological Bulletin, 113(3), 487 - 496.

[10]. Eisenberg, N., Sallquist, J., French, D. C., Purwono, U., Suryanti, T. A., \& Pidada, S. (2009). The Relations of Majority-Minority Group Status and Having an Other-Religion Friend to Indonesian Youths' Socioemotional Functioning. Developmental Psychology, 45(1), 248-259.

[11]. Hamidah. (2002). Perbedaan Kepekaan Sosial Ditinjau Berdasarkan persepsi Remaja terhadap Pola Asuh orang Tua pada Remaja di Jawa Timur. INSAN, 4 (3), 131-160.

[12]. Hambali, K. M., \& Haled, M. H. (2008). Toleransi Beragama dan Amalannya di Malaysia: Rujukan Kepada Artikel 11 Perlembagaan Persekutuan Malaysia. Jurnal Usuluddin, 27, 81-92.

[13]. Hambali, K. M., \& Rahman, N. F. (2013, June). Religious Tolerance in Malaysia: Problems and Challenges. International Journal of Islamic Thought, 3, 81-91.

[14]. Hoeve, M,, Blockland, A., Dubas, J.S., Loeber, R., Gerris, J.R., Laan, P.H. (2008). Trajectories of Deliquency and Parenting Styles. Journal Abnormal Child Psychology, $36,223-235$.

[15]. Hoeve, M., Dubas, J.S., Eichelsheim, V.I., Laan, P.H., Smeenk, W., Gerris, J.R.M. (2009). The Relationship Between Parenting and Deliquency: A Meta-Analysis. Journal Abnormal Child Psychology, 37, 749-775. 
[16]. Homerin, T. E. (2005). Altruism in Islam. In J. Neusner, \& B. Chilton (Eds.), Altruism in world religions (pp. 67-87). Washington, DC: Geogetown University Press.

[17]. Hoorn, J. v., Dijk, E. v., Meuwese, R., Rieffe, C., \& Crone, E. A. (2016). Peer Influence on Prosocial Behavior in Adolescence. Journal of Research on Adolescence, 26(1), 90100.

[18]. Rosli, N. A. (2014). Effect of Parenting Style on children's Emotional and behavioral problems Among Different Ethnicities of Muslim Children in The US.

[19]. Santrock, J.W. (2002). Life Span Development (Perkembangan Masa Hidup) Jilid 2. Jakarta: Penerbit Erlangga.

[20]. Santrock, J.W. (2007). Remaja Jilid 1 (edisi kesebelas). Jakarta: Penerbit Erlangga. 